Pak. J. Agri. Sci., Vol. 55(3), 575-581; 2018

ISSN (Print) 0552-9034, ISSN (Online) 2076-0906

DOI: 10.21162/PAKJAS/18.6694

http://www.pakjas.com.pk

\title{
COMPOSITIONAL PROFILING OF SELECTED PAKISTANI DATE CULTIVARS
}

\author{
Kanza Aziz Awan ${ }^{1, *}$, Masood Sadiq Butt ${ }^{1}$, Mian Kamran Sharif ${ }^{1}$ and Fatma Hussain ${ }^{2}$ \\ ${ }^{1}$ National Institute of Food Science and Technology, University of Agriculture, Faisalabad, Pakistan; ${ }^{2}$ Department of \\ Biochemistry, University of Agriculture, Faisalabad, Pakistan. \\ "Corresponding author's e-mail: kanza_awan@live.com
}

\begin{abstract}
The use of functional foods in the dietary regime proves to be pragmatic approach to ensure better health and well-being. In this regard, date fruit is a promising source of certain essential nutrients. In the present work, the nutritional profile of three selected Pakistani date cultivars namely Dhaki, Aseel and Zahidi was explored. The results indicated that Aseel cultivar contains the highest moisture trailed by Dhaki and Zahidi. More protein was present in the Zahidi cultivar as $4.60 \pm 0.18 \%$ followed by Dhaki and Aseel as $4.22 \pm 0.15$ and $3.72 \pm 0.14 \%$, respectively. However, the crude fat content was higher in Aseel and Zahidi dates as compared to Dhaki $(1.28 \pm 0.04 \%)$. The fiber content was the highest in Zahidi $(7.19 \pm 0.27 \%)$ followed by Dhaki $(6.47 \pm 0.23 \%)$ and Aseel dates $(4.84 \pm 0.17 \%)$. The ash content was recorded as $1.54 \pm 0.06,0.94 \pm 0.03$ and $1.91 \pm 0.07 \%$ in Dhaki, Aseel and Zahidi, respectively. Among the analyzed minerals, potassium was dominant in all the selected varieties. The highest potassium content was found in Zahidi $(870.83 \pm 32.39 \mathrm{mg} / 100 \mathrm{~g})$, followed by Dhaki $(640.23 \pm 24.97 \mathrm{mg} / 100 \mathrm{~g})$ and Aseel $(577.30 \pm 17.90 \mathrm{mg} / 100 \mathrm{~g})$ on fresh weight basis. Calcium was also high in Zahidi as $96.86 \pm 3.18 \mathrm{mg} / 100 \mathrm{~g}$ trailed by Aseel $(58.42 \pm 2.04 \mathrm{mg} / 100 \mathrm{~g})$ and Dhaki $(37.19 \pm 1.30 \mathrm{mg} / 100 \mathrm{~g})$. Similar trend was observed in case of sodium and iron contents. The sugar profile of selected cultivars was assessed chromatographically and results revealed the highest reducing sugars in Zahidi $(39.51 \pm 0.54 \%)$, trailed by Aseel $(34.90 \pm 0.46 \%)$ and Dhaki $(31.31 \pm 0.69 \%)$. Glucose was present in higher amounts in Dhaki as compared to Aseel and Zahidi. While, better fructose content was exhibited by Zahidi followed by Aseel and Dhaki. Maximum amount of sucrose was found in Zahidi variety $(26.15 \pm 0.37 \%)$ trailed by Dhaki $(20.11 \pm 0.29 \%)$ and Aseel $(17.22 \pm 0.24 \%)$.
\end{abstract}

Keywords: Date cultivars, antioxidants, therapeutic properties, proximate, mineral, HPLC, sugars.

\section{INTRODUCTION}

Scientific evidences support the salubrious role of fruits and vegetables in lowering oxidative stress related malfunctions, arising due to imbalance among the reactive oxygen species and natural antioxidant defense mechanisms in the cells and tissues (Perveen et al., 2015). Nowadays, consumers have started subscribing to dietary regimens that prevent the onset and progression of various diseases. In this context, several fruits and vegetables have been studied that possess affirmative health boosting properties (Suleria et al., 2015; Awan et al., 2017). Amongst, dates are being consumed since the primeval times. Date palm and date fruits are valued across the globe due to their significance in the three major religions of the world, Judaism, Christianity and Islam. In Jewish scriptures, dates are among the seven holy foods. Numerous references in the Holy Bible testify the manifold virtues of dates and date palm. However, Islam has given a very high priority to the dates that are regarded as a blessing of the paradise (Holy Quran, 55:68). Health benefits of dates and their nutritional significance have been mentioned in the Holy Quran in several Ayats (Holy Quran 19:23-26). Prophet Muhammad (PBUH) also recommended the consumption of dates owing to its therapeutic properties (Ali et al., 2012; Azarpour et al., 2014; Rahmani et al., 2014). Consumption of dates varies during the year and reaches its peak in the Holy month of Ramadan (Islamic fasting month) when it is used to break the fast. Socioeconomic values also contribute to the consumption pattern depending on the food choices, habits, continued urban drifts as well as the availability of other fruits (Ismail et al., 2006).

Date palm (Phoenix dactylifera) belongs to the Arecaceae family and grows in the hot arid regions of the world. The date fruit is savored for its sweet taste and fleshy mouth feel. About 100 million date palms are present around the globe in nearly 34 countries. The major date growing countries are Egypt, Saudi Arabia, Iran, UAE, Pakistan, Libya, Iraq, Oman and Tunisia (Al-Shahib and Marshall, 2003; Aljasass et al., 2016). In Pakistan, several varieties are being produced particularly in southern Punjab, Sindh and Baluchistan regions, nonetheless, Dhaki, Aseel and Zahidi are the prominent ones (Khan et al., 2008). Dates are categorized on the basis of shape, moisture content, sugar level and sensory properties. More than 600 varieties of date fruit have been identified and are consumed globally (Baliga et al., 2011). However, evidence based insights suggest the compositional variations 
existing in the dates cultivated all along the globe even within the same region. Therefore, the present research was planned to elucidate the compositional characteristics of three prominent date varieties consumed in Pakistan.

\section{MATERIALS AND METHODS}

Raw material procurement: The research was carried out in the Functional and Nutraceutical Food Research Section of National Institute of Food Science and Technology (NIFSAT), University of Agriculture, Faisalabad. Three date cultivars i.e. Dhaki, Aseel and Zahidi were selected. Dhaki was procured from Date Research Institute while Aseel and Zahidi were purchased from the Faisalabad's local market. The date samples were graded based on size uniformity, physical defects and color.

Sample preparation: The date fruit samples after washing were cleaned using a tissue paper, air-dried $\left(10^{\circ} \mathrm{C}\right)$ and pitted. The fruit pulp was minced using an electric mincer and the samples were kept in polyethylene bags at $4^{\circ} \mathrm{C}$ for further analyses.

Chemical characterization of date fruit: The date fruit varieties were analyzed for various compositional traits including proximate assay and mineral profiles.

Moisture content: Date pulp was analyzed for moisture content determination following AOAC (2006) Method No. 934-01. Purposely, $10 \mathrm{~g}$ of the date sample was dried in the hot air oven (DO-1-30-02, PCSIR, Pakistan) at $105 \pm 5^{\circ} \mathrm{C}$ temperature until constant weight.

Moisture $(\%)=$

$\frac{\text { Weight of fresh sample }(\mathrm{g}) \text {-Weight of dried sample }(\mathrm{g})}{\text { Weight of fresh sample }(\mathrm{g})} \times 100$

Crude protein content: Kjeltech apparatus (D-40599, Behr Labor Technik, Germany) was employed to measure the percent nitrogen in date samples according to the AOAC (2006) Method No. 984-13. In this regard, $500 \mathrm{mg}$ of each date sample was digested using concentrated $\mathrm{H}_{2} \mathrm{SO}_{4}$ along with the digestion tablet $\left(\mathrm{K}_{2} \mathrm{SO}_{4}: \mathrm{FeSO}_{4}: \mathrm{CuSO}_{4}::\right.$ 100:5:10) until the color was light greenish (three to four hours). The digested sample was then added to $250 \mathrm{~mL}$ volumetric flask and volume was made up to the mark using distilled water. Afterwards, $10 \mathrm{~mL}$ of $40 \%$ sodium hydroxide and $10 \mathrm{~mL}$ digested sample were taken in the distillation apparatus, where the liberated ammonia was added to the flask containing $4 \%$ solution of boric acid and one to two drops of methyl red indicator. This lead to the ammonium borate formation which was then used for the determination of nitrogen in the sample. The nitrogen percentage in the date samples was assessed by titrating the distillate against $0.1 \mathrm{~N}$ solution of $\mathrm{H}_{2} \mathrm{SO}_{4}$ till the appearance of light golden color. The content of crude protein was determined by multiplying the nitrogen percentage with the factor 5.80.
Nitrogen $(\%)=$

Volume of $0.1 \mathrm{~N}$ sulphuric acid used $\times 0.0014 \times 250$

Sample weight $\times$ Aliquot volume

Crude protein $(\%)=$ Nitrogen $(\%) \times 5.80$

Crude fat: The crude fat in the date fruit samples was ascertained according to the Method No. 920-39 of AOAC (2006). For the purpose, $2 \mathrm{~g}$ moisture free sample was weighed and taken in a thimble. Then, $50 \mathrm{~mL}$-hexane as a solvent was added into the flask that was attached to the soxhlet (H-2 1045 Extraction Unit, Hoganas, Sweden). Fat content in the date sample was extracted for 2-3 hours in the soxhlet by regulating the flow rate to 3-4 drops per second of n-hexane. After six to seven siphon back, the thimble was removed and dried in an hot air oven at constant temperature $\left(105^{\circ} \mathrm{C}\right)$ for constant time ( 1 hour) and then weighed using electric balance.

$$
\text { Crude fat }(\%)=\frac{\text { Weight of hexane extract }(\mathrm{g})}{\text { Weight of sample }} \times 100
$$

Crude fiber: The content of crude fiber in date samples was measured by using the Method No. 978-10 as per the guidelines of AOAC (2006). Purposely, $2 \mathrm{~g}$ fat free date sample was digested using $1.25 \%$ of boiling $\mathrm{H}_{2} \mathrm{SO}_{4}(200 \mathrm{~mL})$ for 30 minutes in the Fibertech apparatus (Labconco Corporation, Kansas, USA). Sulphuric acid was drained out and the digested sample was then filtered and washed three times using boiling distilled water to ensure acid free sample. Afterwards, it was again digested for 30 minutes in $200 \mathrm{~mL}$ boiling sodium hydroxide $(1.25 \%)$. The sodium hydroxide was then drained out and the digested sample was again filtered and washed three times with boiling distilled water to make free from alkali residues. The residue obtained was then dried at predefined temperature $\left(130^{\circ} \mathrm{C}\right)$ and time ( 2 hours) and weighed $\left(\mathrm{W}_{1}\right)$. The oven dried sample was ignited in the muffle furnace (MF-1/02, PCSIR, Pakistan) at temperature of $550-650^{\circ} \mathrm{C}$ till white ash was obtained and reweighed $\left(\mathrm{W}_{2}\right)$. The percent crude fiber in the date fruit samples was obtained by using the following expression:-

$$
\text { Crude fiber }(\%)=\frac{\mathrm{W} 1-\mathrm{W} 2}{\text { Sample weight }(\mathrm{g})} \times 100
$$

Ash content: Total ash content was assessed by incineration of the sample following the procedure as mentioned in AOAC (2006) Method No. 942-05. Accordingly, 5 g sample was taken in a crucible and directly charred on flame until fumeless. Afterwards, the sample was ignited in the muffle furnace (MF-1/02, PCSIR, Pakistan) at a temperature of 550$600^{\circ} \mathrm{C}$ for about 5-6 hours' time period till greyish white residues. The ash percentage in each date sample was computed using the following mathematical expression:

$$
\text { Ash }(\%)=\frac{\text { Weight of Ash }(\mathrm{g})}{\text { Weight of sample }(\mathrm{g})} \times 100
$$

Nitrogen free extract (NFE): The NFE in date samples was calculated according to the following formula: 
$\operatorname{NFE}(\%)=100-(\%$ moisture $+\%$ ash $+\%$ crude fat $+\%$ crude fiber $+\%$ crude protein

Mineral analysis: Date fruit samples were analyzed for their mineral contents following AOAC (2006) method. Purposely, $3 \mathrm{~g}$ date sample was incinerated and ashed at $550^{\circ} \mathrm{C}$ in the muffle furnace. The obtained ash was then dissolved in fuming nitric acid $(5 \mathrm{~mL})$ and shifted to a volumetric flask $(50 \mathrm{~mL})$ using double distilled deionized water. For the preparation of standard solutions of each element, $250 \mu \mathrm{L}$ was taken from the standard stock solution $(1000 \mathrm{mg} / \mathrm{L})$ in a $25 \mathrm{~mL}$ volumetric flask and made up to the mark with $0.5 \mathrm{~N}$ HCL solution hence prepared the intermediate standard solution $(10 \mathrm{mg} / \mathrm{L})$. Working control solutions suitable to the concentration of each element in the sample solution were prepared. The date samples and controls were ascertained using Flame Photometer-410 (Sherwood Scientific Ltd., Cambridge) for potassium and sodium as per method no 956.01 (AOAC 2006). While, calcium, copper, cobalt, magnesium, iron, manganese and zinc in the resultant samples were determined by using Atomic Absorption Spectrophotometer (Hitachi Polarized Zeeman AAS, Z-8200, Japan) according to the conditions described in AOAC (2006) Method No. 975.03 (b) and 991.11. Commercially available stock solution (Applichem $\left.{ }^{\circledR}\right) 1000$ ppm in the form of an aqueous solution was used for the preparation of calibrated standards. While, highly purified deionized water was using for the preparation of the working standards. All the glass apparatus that was used during the analytical process were immersed in $8 \mathrm{~N}$ nitric acid solution overnight and washed several times with de-ionized water before using.

Sugar content determination: The sugar content in the selected date fruit samples were determined according to the protocol described by Chaira et al. (2009). The fresh date flesh weighing $5 \mathrm{~g}$ was refluxed with $25 \mathrm{~mL}$ HPLC grade water. The mixture was homogenized for 5 minutes at 280 rpm using orbital shaker and allowed to rest for 2 hours. Afterwards, it was centrifuged using at $5000 \mathrm{rpm}$ for 10 minutes at $4{ }^{\circ} \mathrm{C}$. The supernatant was filtered via $0.45 \mu \mathrm{m}$ membrane filter. HPLC was used to quantify the reducing and non-reducing sugars in the date samples. The separation was conducted at $20^{\circ} \mathrm{C}$ room temperature on Lichrospher ${ }^{\circledR} 100$ $\mathrm{NH}_{2}$ Purospher@STAR $\mathrm{NH}_{2} 5 \mu \mathrm{m}$ column. The mobile phase comprised of acetonitrile and ultrapure water $(80 / 20 \mathrm{v} / \mathrm{v})$. The liquid chromatographic system was connected to refractive index detector 10 A. $0.8 \mathrm{~mL} /$ minute flow rate and $20 \mathrm{~mL}$ injection volume was set throughout the test. The integrator was calibrated using the external standards consisting of $2 \%$ fructose, $2 \%$ glucose and $1 \%$ sucrose solutions. The total reducing sugars were calculated by adding the obtained glucose and fructose contents.

Statistical modeling: The obtained data were subjected to statistical analysis to ascertain the level of significance. Completely randomized design (CRD) was applied using
Statistical Package (Statistix 8.1) outlined by Mason et al. (2003). Significant ranges were further compared by post-hoc Tukey's HSD test.

\section{RESULTS}

Compositional profiling: The compositional traits of date fruit are imperative in determining its degree of maturation and predicted shelf life. These traits are related to its nutritional significance and possible health benefits. The first module of the study comprised of the detailed compositional profiling of the selected date varieties. The results regarding the composition are discussed below:

Proximate composition: Dates were analyzed for various quality attributes. The statistical analysis depicted significant variations in proximate composition of Dhaki, Aseel and Zahidi. It is evident from Table 1 that Aseel contains maximum moisture $(17.71 \pm 0.67 \%)$ trailed by Dhaki $(15.54 \pm 0.54 \%)$ and Zahidi $(10.50 \pm 0.39 \%)$ cultivars. The protein content is higher in Zahidi as $4.60 \pm 0.18 \%$ followed by Dhaki and Aseel as $4.22 \pm 0.15$ and $3.72 \pm 0.14 \%$, respectively. Dhaki, Aseel and Zahidi dates contain 1.28 $\pm 0.04,2.61 \pm 0.08$ and $2.08 \pm 0.07 \%$ crude fat, respectively. Whereas, the fiber content was more in the Zahidi cultivar $(7.19 \pm 0.27 \%)$ followed by Dhaki $(6.47 \pm 0.23 \%)$ and Aseel $(4.84 \pm 0.17 \%)$. The ash content was recorded as $1.54 \pm 0.06,0.94 \pm 0.03$ and $1.91 \pm 0.07 \%$ in Dhaki, Aseel and Zahidi, correspondingly. The maximum NFE was found in Zahidi dates $(73.72 \pm 2.65 \%)$, while minimum in the Aseel dates $(70.19 \pm 2.11 \%)$.

Table 1. Proximate composition of selected date cultivars $(n=3)$.

\begin{tabular}{lcrr}
\hline $\begin{array}{l}\text { Compositional } \\
\text { analyses }(\%)\end{array}$ & Dhaki & Aseel & Zahidi \\
\hline Moisture & $15.54 \pm 0.54 \mathrm{~b}$ & $17.71 \pm 0.67 \mathrm{a}$ & $10.50 \pm 0.39 \mathrm{c}$ \\
Crude protein & $4.22 \pm 0.15 \mathrm{ab}$ & $3.72 \pm 0.14 \mathrm{~b}$ & $4.60 \pm 0.18 \mathrm{a}$ \\
Crude fat & $1.28 \pm 0.04 \mathrm{c}$ & $2.61 \pm 0.08 \mathrm{a}$ & $2.08 \pm 0.07 \mathrm{~b}$ \\
Crude fiber & $6.47 \pm 0.23 \mathrm{a}$ & $4.84 \pm 0.17 \mathrm{~b}$ & $7.19 \pm 0.27 \mathrm{a}$ \\
Ash & $1.54 \pm 0.06 \mathrm{~b}$ & $0.94 \pm 0.03 \mathrm{c}$ & $1.91 \pm 0.07 \mathrm{a}$ \\
Nitrogen free & $70.95 \pm 2.36$ & $70.19 \pm 2.11$ & $73.72 \pm 2.65$ \\
extract & & & \\
\hline
\end{tabular}

Values represent mean \pm SD; One-way ANOVA followed by Tukey's HSD multiple comparison tests; Means carrying same letters have no significant difference.

The results of the present study are in agreement with the previous studies involving other date cultivars (Al-Shahib and Marshall, 2003; Al-Farsi et al., 2005; Bouhlali et al., 2017). The findings of the current investigation are also in line with the work of Mohamed et al. (2014) on five Sudanese date varieties in which the moisture content ranged from 8.78 to $10.68 \mathrm{~g} / 100 \mathrm{~g}$ and ash 1.96 to $2.50 \mathrm{~g} / 100 \mathrm{~g}$. The varieties contained 78.73-80.41 g/100g carbohydrates, 2.37-3.14 $\mathrm{g} / 100 \mathrm{~g}$ fiber, 3.69 to $4.09 \mathrm{~g} / 100 \mathrm{~g}$ protein and 1.71-2.06 
$\mathrm{g} / 100 \mathrm{~g}$ fat. Results suggest significant variations in the compositional traits like moisture, ash, carbohydrates and fat among the varieties. However, all the cultivars contained almost same amount of protein. El-Sohaimy and Hafez (2010) elucidated the biochemical profile of Egyptian date varieties and found that those cultivars contain moisture $(13.80 \%)$, protein $(3.00 \%)$, fat $(2.90 \%)$, crude fiber $(5.20 \%)$ and ash $(2.13 \%)$. The overall chemical properties also relate to the work of Borchani et al. (2010) who analyzed the biochemical composition of 11 Tunisian date cultivars and concluded that Tunisian dates contain 9.43 to $23.34 \%$ moisture, 0.46 to $2.85 \%$ protein, 0.06 to $0.57 \%$ fat, 1.58 to $2.59 \%$ ash and 8.09 to $20.25 \%$ total dietary fiber. Similar compositional traits were reported by Ali et al. (2009) for Omani date varieties. The health promoting potential of dates can also be attributed to the healthy components in the matrix, it contains less amount of fat along with more fiber and the higher ash content that also signifies the presence of more minerals. Moreover, the protein content is not very high but the scientific investigations declare that dates contain suitable amounts of several essential amino acids that include glycine, valine, histidine, aspartic acid, proline, arginine and leucine (ElSohaimy and Hafez, 2010). Bouhlali et al. (2017) stated that $100 \mathrm{~g}$ dates can provide 9.94 to $18.86 \%$ of an adult daily energy requirements. In the present study, the compositional characteristics varied significantly with respect to varieties. However, the cultivar having the lowest moisture content i.e. Zahidi contained higher amounts of protein, fiber, ash and NFE, while Dhaki also possessed good composition after Zahidi. Besides, the Aseel variety contented highest moisture and fat content among the three cultivars. The high fat content could also be due to the fact that Aseel dates are coated with a very thin layer of oil to improve their shelf stability and luster before reaching to the market. These outcomes and previous findings clearly shows that considerable variations exist among the varieties of same region as well as different regions, these differences can be related to the geographical conditions of a particular area and genetic variations among the cultivars.

Mineral profile: Micronutrients are involved in all cellular and metabolic processes. They play significant role in the growth and development. These entities are required in small amounts but their absence may lead to severe complications (Sultan et al., 2014). Mineral content determination indicated that potassium is dominant in all the selected varieties. Highest potassium content was found in Zahidi dates $(870.83 \pm 32.39 \mathrm{mg} / 100 \mathrm{~g})$, followed by Dhaki $(640.23 \pm 24.97$ $\mathrm{mg} / 100 \mathrm{~g})$ and Aseel $(577.30 \pm 17.90)$. Calcium content was also higher in Zahidi as $96.86 \pm 3.18 \mathrm{mg} / 100 \mathrm{~g}$ trailed by Aseel $(58.42 \pm 2.04 \mathrm{mg} / 100 \mathrm{~g})$ and Dhaki $(37.19 \pm 1.30 \mathrm{mg} / 100 \mathrm{~g})$. Similar trend was observed in case of sodium, as highest content of $8.49 \pm 0.31 \mathrm{mg} / 100 \mathrm{~g}$ was found in Zahidi and lowest in Dhaki $(3.27 \pm 0.10 \mathrm{mg} / 100 \mathrm{~g})$ on fresh weight basis (Table 2).
However, Aseel contained $6.37 \pm 0.27 \mathrm{mg} / 100 \mathrm{~g}$ sodium. Iron was also higher in Zahidi variety as compared to the other two cultivars. The recorded iron contents for Dhaki, Aseel and Zahidi were $1.98 \pm 0.07,1.58 \pm 0.04$ and $3.23 \pm 0.11 \mathrm{mg} / 100 \mathrm{~g}$, respectively. Micro mineral profile showed maximum zinc content in Aseel $(0.82 \pm 0.03 \mathrm{mg} / 100 \mathrm{~g})$ followed by Zahidi $(0.52 \pm 0.01 \mathrm{mg} / 100 \mathrm{~g})$ and lowest in Dhaki $(0.33 \pm 0.01$ $\mathrm{mg} / 100 \mathrm{~g})$. The manganese content was more in Zahidi $(0.52 \pm 0.02 \mathrm{mg} / 100 \mathrm{~g})$, while Dhaki and Aseel contained similar amounts as $0.41 \pm 0.02$ and $0.41 \pm 0.02 \mathrm{mg} / 100 \mathrm{~g}$, respectively. Likewise, copper was higher in Zahidi as $0.65 \pm 0.02 \mathrm{mg} / 100 \mathrm{~g}$ trailed by Aseel $0.34 \pm 0.01$ and Dhaki $0.25 \pm 0.01 \mathrm{mg} / 100 \mathrm{~g}$. Maximum cobalt content $0.50 \pm 0.02$ $\mathrm{mg} / 100 \mathrm{~g}$ was found in Dhaki variety, followed by Aseel $0.48 \pm 0.02 \mathrm{mg} / 100 \mathrm{~g}$ and minimum in the Zahidi cultivar0.39 $\pm 0.01 \mathrm{mg} / 100 \mathrm{~g}$.

Table 2. Mineral content distribution in selected date cultivars $(n=3)$.

\begin{tabular}{lrrr}
\hline $\begin{array}{l}\text { Minerals } \\
(\mathbf{m g} / \mathbf{1 0 0 g}\end{array}$ & Dhaki & \multicolumn{1}{c}{ Aseel } & \multicolumn{1}{c}{ Zahidi } \\
F.W. $)$ & & & \\
\hline Potassium & $640.23 \pm 25.0 \mathrm{~b}$ & $577.30 \pm 17.9 \mathrm{c}$ & $870.83 \pm 32.4 \mathrm{a}$ \\
Calcium & $37.19 \pm 1.30 \mathrm{c}$ & $58.42 \pm 2.04 \mathrm{~b}$ & $96.86 \pm 3.18 \mathrm{a}$ \\
Sodium & $3.27 \pm 0.10 \mathrm{c}$ & $6.37 \pm 0.27 \mathrm{~b}$ & $8.49 \pm 0.31 \mathrm{a}$ \\
Iron & $1.98 \pm 0.07 \mathrm{~b}$ & $1.58 \pm 0.04 \mathrm{c}$ & $3.23 \pm 0.11 \mathrm{a}$ \\
Zinc & $0.33 \pm 0.01 \mathrm{c}$ & $0.82 \pm 0.03 \mathrm{a}$ & $0.52 \pm 0.01 \mathrm{~b}$ \\
Manganese & $0.41 \pm 0.02 \mathrm{~b}$ & $0.41 \pm 0.02 \mathrm{~b}$ & $0.52 \pm 0.02 \mathrm{a}$ \\
Copper & $0.25 \pm 0.01 \mathrm{c}$ & $0.34 \pm 0.01 \mathrm{~b}$ & $0.65 \pm 0.02 \mathrm{a}$ \\
Cobalt & $0.50 \pm 0.02 \mathrm{a}$ & $0.48 \pm 0.02 \mathrm{a}$ & $0.39 \pm 0.01 \mathrm{~b}$ \\
\hline
\end{tabular}

Values represent mean \pm SD; One-way ANOVA followed by Tukey's HSD multiple comparison tests; Means carrying same letters have no significant difference.

Mineral content in a particular food also depends on the type of soil. Similar results were delineated by Mohamed et al. (2014) for six Sudanese date varieties. Their results reveals the presence of calcium (222.20-293.04 mg/100g), magnesium (66.30-120.88 mg/100g), sodium (55.56-139.11 $\mathrm{mg} / 100 \mathrm{~g})$, potassium (691.67-1088.40 $\mathrm{mg} / 100 \mathrm{~g})$ and phosphorous (150.19-232.04 mg/100g). Among the micro minerals, iron (4.06-7.06 $\mathrm{mg} / 100 \mathrm{~g})$, copper (0.71-1.86 $\mathrm{mg} / 100 \mathrm{~g})$, zinc $(0.66-1.00 \mathrm{mg} / 100 \mathrm{~g})$ and manganese $(0.54-$ $0.78 \mathrm{mg} / 100 \mathrm{~g}$ ) were present. The broader ranges covers almost all characterized minerals in the present study, however, low sodium content was found the Pakistani varieties as compared to the Sudanese. The potassium and calcium content in the Egyptian date cultivars was similar to the Aseel cultivar i.e. 521 and $65 \mathrm{mg} / 100 \mathrm{~g}$, respectively as described by El-Sohaimy and Hafez (2010). In 11 explored Tunisian date cultivars, the potassium content ranged from 404.19 to $774.71 \mathrm{mg} / 100 \mathrm{~g}$ that is slightly lower from the potassium content in the studied Zahidi dates, while the other two varieties fits well in the given range. Likewise, those cultivars also contain lower calcium content than Zahidi with 
maximum value of $36.52 \mathrm{mg} / 100 \mathrm{~g}$. The sodium and iron content in Tunisian dates range from 5.27 to 25.14 and 1.06 to $2.30 \mathrm{mg} / 100 \mathrm{~g}$, respectively (Borchani et al., 2010) that are somewhat similar to the studied dates. The outcomes are also in corroboration with the earlier findings of Bouhlali et al. (2017) who studied the mineral composition of eight date varieties from Morocco having higher potassium, calcium and magnesium content as compared to the other minerals. The variations in the mineral content as explained earlier might be a reason of varietal, environmental, genetic and phenotypic (Naqvi et al., 2015) dissimilarities amongst the cultivars.

The results clearly show that dates are promising source of minerals especially potassium, calcium, iron and zinc. Studies also suggest the presence of selenium in date fruit that can also responsible for its beneficial activities (Baliga et al., 2011). Scientific evidences suggest that dietary intake of copper and manganese plays an imperative role in modulating the blood pressure and ameliorating the lipid profile (Kim and Choi, 2013). These minerals along with iron and zinc are integral to many metabolic pathways (Ahmed et al., 2014). Specially zinc, iron and manganese are amongst the highly utilized metals by the enzymes in the biological catalysis (Andreini et al., 2008). Besides, Aaron and Sanders (2013) deduced that dietary potassium attenuates endothelial dysfunction, hypertension and kidney disease progression as a result of excessive salt intake. Recent meta-analysis and clinical trials are also focusing on sodium reduction and potassium supplementation for lowering the incidence of hypertension and morbidity from the cardiovascular events (Whelton and He, 2014). Higher potassium consumption is concomitant with a $24 \%$ decreased stroke risk according to a meta-analyses (Aburto et al., 2013). Hence, high potassium content in date fruit coupled with low sodium content may serve as an approach towards the control of hypertension and related ailments. Among the analyzed cultivars, Zahidi cultivar contains better potassium, calcium, copper, iron and manganese content as compared to Dhaki and Aseel. Incorporating Zahidi dates in the daily diet could be a preventive measure against various physiological threats.

Sugars: The total carbohydrate content determined through approximate method was highest in the Zahidi variety as $80.91 \pm 2.82 \%$ followed by Dhaki $77.42 \pm 2.51 \%$ and Aseel $75.03 \pm 2.18 \%$. The HPLC determination of reducing and nonreducing sugars revealed highest reducing sugars in Zahidi $(39.51 \pm 0.54 \%)$ trailed by Aseel $(34.90 \pm 0.46 \%)$ and Dhaki $(31.31 \pm 0.69 \%)$. Amongst, glucose was present in higher amounts in Dhaki as $12.61 \pm 0.15 \%$ as compared to Aseel $9.10 \pm 0.13 \%$ and Zahidi $10.41 \pm 1.49 \%$ varieties. While, better fructose content was exhibited by Zahidi i.e. $29.10 \pm 0.38 \%$ followed by Aseel $25.80 \pm 0.37 \%$ and Dhaki $18.70 \pm 0.28 \%$. The fructose to glucose ratio was $1.48 \pm 0.02,2.84 \pm 0.04$ and $2.79 \pm 0.04$ in Dhaki, Aseel and Zahidi cultivars, respectively. Maximum amount of sucrose (the non-reducing sugar) was found in the Zahidi variety $(26.15 \pm 0.37 \%)$ followed by Dhaki
$(20.11 \pm 0.29 \%)$. Whilst, minimum sucrose content was recorded for Aseel i.e. 17.22 $\pm 0.24 \%$ (Table 3). The HPLC chromatograms are displayed in Figure 1.

Table 3. Sugar profiling of selected date cultivars $(n=3)$.

\begin{tabular}{lcrr}
\hline Sugars (\%) & \multicolumn{1}{c}{ Dhaki } & \multicolumn{1}{c}{ Aseel } & \multicolumn{1}{c}{ Zahidi } \\
\hline Total & $77.42 \pm 2.51 \mathrm{~b}$ & $75.03 \pm 2.18 \mathrm{~b}$ & $80.91 \pm 2.82 \mathrm{a}$ \\
Carbohydrates & & & \\
Reducing Sugars & $31.31 \pm 0.69 \mathrm{c}$ & $34.90 \pm 0.46 \mathrm{~b}$ & $39.51 \pm 0.54 \mathrm{a}$ \\
Glucose & $12.61 \pm 0.15 \mathrm{a}$ & $9.10 \pm 0.13 \mathrm{c}$ & $10.41 \pm 1.49 \mathrm{~b}$ \\
Fructose & $18.70 \pm 0.28 \mathrm{c}$ & $25.80 \pm 0.37 \mathrm{~b}$ & $29.10 \pm 0.38 \mathrm{a}$ \\
F/G Ratio & $1.48 \pm 0.02 \mathrm{~b}$ & $2.84 \pm 0.04 \mathrm{a}$ & $2.79 \pm 0.04 \mathrm{a}$ \\
Non-reducing & $20.11 \pm 0.27 \mathrm{~b}$ & $17.22 \pm 0.23 \mathrm{c}$ & $26.15 \pm 0.35 \mathrm{a}$ \\
Sugar (Sucrose) & & & \\
Total Sugars & $51.42 \pm 0.81 \mathrm{~b}$ & $52.12 \pm 0.75 \mathrm{~b}$ & $65.66 \pm 0.91 \mathrm{a}$ \\
\hline
\end{tabular}

Values represent mean \pm SD; One-way ANOVA followed by Tukey's HSD multiple comparison tests;

Means carrying same letters have no significant difference.
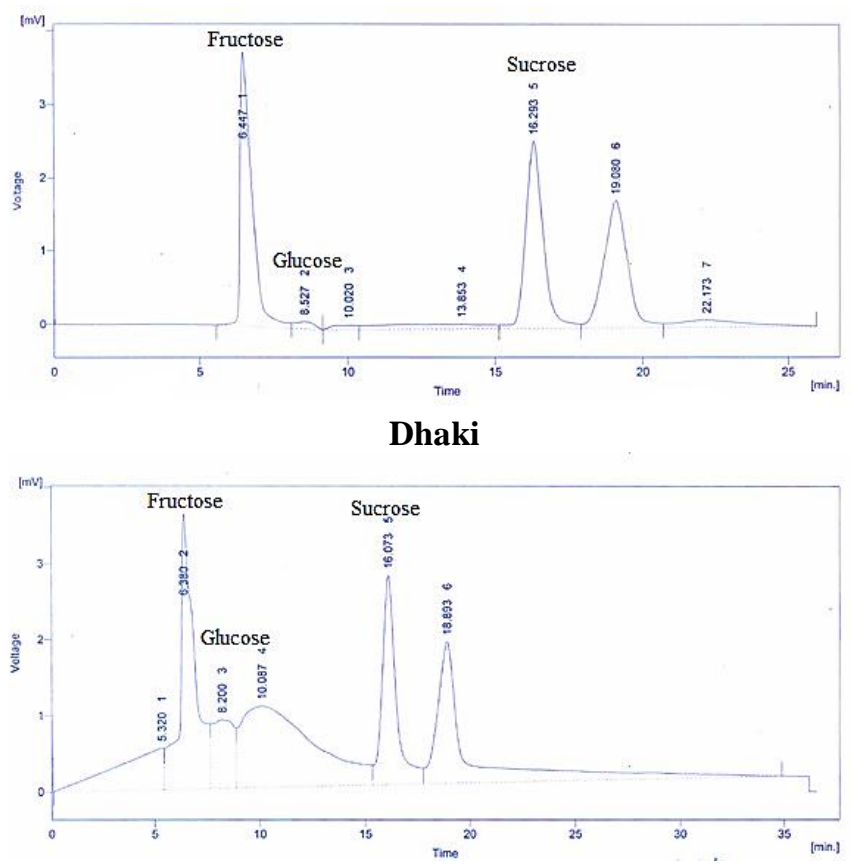

Aseel

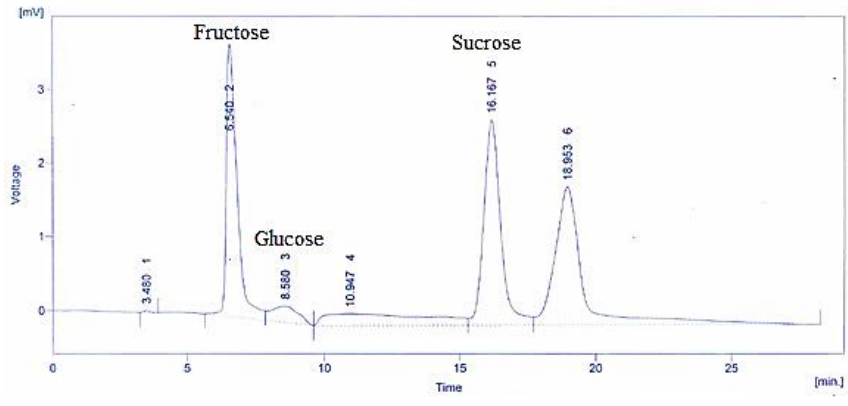

Zahidi

Figure 1. HPLC chromatograms of sugars in selected date cultivars. 
The findings of Al-Asmari et al. (2017) regarding the sugars in Saudi date cultivars shows more sugar content in those cultivars as compared to the ones studied. The selected Saudi cultivars contains sucrose $42.85-43.78 \%$, glucose 33.58 $34.93 \%$ and fructose $22.20-22.67 \%$, while the glucose to fructose ratio varies from 1.48 to 1.57 . The difference in the sugar content may be attributed to the physicochemical composition of the varieties. Higher moisture content was also reported in the aforementioned cultivars. A change in the concentration and types of sugars is also associated with the developmental stages. The results are also in harmony with the findings of El-Sohaimy and Hafez (2010) regarding the sugar profile of Egyptian dates. The Egyptian date cultivars contained $73 \%$ carbohydrates. The reported dominant sugars were glucose, fructose and sucrose, while lower amounts of xylose, lactose, mannose and lactulose were also quantified. The results are also in agreement with the outcomes of Borchani et al. (2010) who reported 79.93 to $88.02 \%$ carbohydrates in 11 date cultivars of Tunisia. Amongst the sugars, more reducing sugars were found as compared to sucrose except a few cultivars that contained more nonreducing sugars as Deglet Nour. The glucose and fructose content ranged from 19.85 to $44.79 \%$ and 16.54 to $41.17 \%$, respectively. The sucrose content was as low as $0.63 \%$ in Touzerzaillet variety and as high as $51.14 \%$ in the Deglet Nour. Similar outcomes were obtained by Bouhlali et al. (2015) regarding the Moroccan date cultivars with more reducing sugars. These sugars present in the fruit dates; glucose, fructose and sucrose are easily digestible and are required for energy production and various other metabolic processes. Moreover, Ali et al. (2009) inferred that dates can be considered as low to medium glycemic index foods, thus can be an effective part of healthy diet planning for diabetic, obese or heart patients. The present results also suggest that Zahidi is sweeter than Dhaki and Aseel, hence it can be incorporated in food products as a natural sweetener.

Conclusions: The selected Pakistani date varieties namely Dhaki, Zahidi and Aseel contains an optimal mix of nutrients required for a healthy living. However, the content varies among the varieties. Need of the day is to utilize these benefiting nutrients in regular dietary regime as well as in the development of novel value added date based functional products. It is also anticipated that the rich mineral profile of the fruit may also be responsible in alleviating the disease risk. Moreover, being a rich source of sugars, the fruit can also be used to replace the table sugar in confections and baked goods.

Conflict of interest statement: The authors declare no conflict of interest.

\section{REFERENCES}

Aaron, K.J. and P.W. Sanders. 2013. Role of dietary salt and potassium intake in cardiovascular health and disease: A review of the evidence. Mayo Cli. Proc. Elsevier. 88:987995.

Aburto, N.J., S. Hanson, H. Gutierrez, L. Hooper, P. Elliott and F.P. Cappuccio. 2013. Effect of increased potassium intake on cardiovascular risk factors and disease: systematic review and meta-analyses. B.M.J. 346:1-19.

Ahmed, A., A. Ahmad, N. Khalid, A. David, M.A. Sandhu, M.A. Randhawa and H.A.R Suleria. 2014. A question mark on iron deficiency in 185 million people of pakistan: Its outcomes and prevention. Crit. Rev. Food Sci. Nutr. 54:1617-1635.

Al-Farsi, M., C. Alasalvar, A. Morris, M. Baron and F. Shahidi. 2005. Compositional and sensory characteristics of three native sun-dried date (Phoenix dactylifera L.) varieties grown in Oman. J. Agric. Food Chem. 53:75867591.

Ali, A., M. Waly, M.M. Essa and S. Devarajan. 2012. Nutritional and medicinal value of date fruit. In: Manickavasagan, A., M. Essa and E. Sukumar (Eds.). Dates: Production, Processing, Food, and Medicinal Values. CRC Press, Boca Raton, Florida. p.361.

Ali, A., Y.S.M. Al-Kindi and F. Al-Said. 2009. Chemical composition and glycemic index of three varieties of Omani dates. Int. J. Food Sci. Nutr. 60:51-62.

Aljasass, F.M., S.M. Aleid and S.H. Hamad. 2016. Potential pathogenic yeasts isolated from fresh date fruits (Rutab). Pak. J. Agri. Sci. 53:461-465.

Al-Asmari, F., N. Nirmal, M. Chaliha, D. Williams, R. Mereddy, K. Shelat and Y. Sultanbawa. 2017. Physicochemical characteristics and fungal profile of four Saudi fresh date (Phoenix dactylifera $\mathrm{L}$.) cultivars. Food Chem. 221:644-649.

Al-Shahib, W. and R.J. Marshall. 2003. The fruit of the date palm: Its possible use as the best food for the future. Int. J. Food Sci. Nutr. 54:247-259.

Awan, K., M. Butt, I. Haq, F. Ashfaq and H. Suleria. 2017. Storage stability of garlic fortified chicken bites. J. Food Chem. Nanotechnol. 3:80-85.

Andreini, C., I. Bertini, G. Cavallaro, G.L. Holliday and J.M. Thornton. 2008. Metal ions in biological catalysis: From enzyme databases to general principles. J. Biol. Inorganic Chem. 13:1205-1218.

AOAC. 2006. Official Methods of Analysis of Association of Official Analytical Chemists International, $18^{\text {th }} \mathrm{Ed}$, AOAC Press, Arlington, VA, USA.

Azarpour, E., M. Moraditochaee and H.R. Bozorgi. 2014. Nutritional and biochemical compounds of Quranic plants. Biol. Forum-Int. J. 6:242-248.

Baliga, M.S., B.R.V. Baliga, S.M. Kandathil, H.P. Bhat and P.K. Vayalil. 2011. A review of the chemistry and 
pharmacology of the date fruits (Phoenix dactylifera L.). Food Res. Int. 44:1812-1822.

Borchani, C., S. Besbes, C. Blecker, M. Masmoudi, R. Baati and H. Attia. 2010. Chemical properties of 11 date cultivars and their corresponding fiber extracts. Afr. J. Biotechnol. 9:4096-4105.

Bouhlali, E.D.T., M. Ramchoun, C. Alem, K. Ghafoor, J. Ennassir and Y.F. Zegzouti. 2017. Functional composition and antioxidant activities of eight Moroccan date fruit varieties (Phoenix dactylifera L.). J. Saudi Soc. Agri. Sci. 16:257-264.

Chaira, N., A. Mrabet and A. Ferchichi. 2009. Evaluation of antioxidant activity, phenolics, sugar and mineral contents in date palm fruits. J. Food Biochem. 33:390403.

El-Sohaimy, S.A. and E.E. Hafez. 2010. Biochemical and nutritional characterizations of date palm fruits (Phoenix dactylifera 1.). J. App. Sci. Res. 6:1060-1067.

Ismail, B., I. Haffar, R. Baalbaki, Y. Mechref and J. Henry. 2006. Physicochemical characteristics and total quality of five date varieties grown in the United Arab Emirates. Int. J. Food Sci. Technol. 41:919-926.

Khan, M.N., A. Sarwar, M.F. Wahab and R. Haleem. 2008. Physico-chemical characterization of date varieties using multivariate analysis. J. Sci. Food Agri. 88:1051-1059.

Kim, M.H. and M.K. Choi. 2013. Seven dietary minerals (Ca, $\mathrm{P}, \mathrm{Mg}, \mathrm{Fe}, \mathrm{Zn}, \mathrm{Cu}$, and $\mathrm{Mn}$ ) and their relationship with blood pressure and blood lipids in healthy adults with self-selected diet. Biol. Trace Elem. Res. 153:69-75.

Mason, R.L., R.F. Gunst and J.L. Hess. 2003. Statistical Design and Analysis of Experiments: With Applications to Engineering and Science. John Wiley \& Sons, New Jersey, USA.
Mohamed, R.M., A.S. Fageer, M.M. Eltayeb and I.A. Mohamed Ahmed. 2014. Chemical composition, antioxidant capacity, and mineral extractability of Sudanese date palm (Phoenix dactylifera L.) fruits. Food Sci. Nutr. 2:478-489.

Naqvi, S.A., I.A. Khan, J.C. Pintaud, M.J. Jaskani and A. Ali. 2015. Morphological characterization of Pakistani date palm (Phoenix dactylifera L.) genotypes. Pak. J. Agri. Sci. 52:645-650.

Perveen, R., H.A.R. Suleria, F.M. Anjum, M.S. Butt, I. Pasha and S. Ahmad. 2015. Tomato (Solanum lycopersicum) carotenoids and lycopenes chemistry; metabolism, absorption, nutrition, and allied health claims- A comprehensive review. Crit. Rev. Food Sci. Nutr. 55:919-929.

Rahmani, A.H., S.M. Aly, H. Ali, A.Y. Babiker, S. Srikar and A.A. Khan. 2014. Therapeutic effects of date fruits (Phoenix dactylifera) in the prevention of diseases via modulation of anti-inflammatory, anti-oxidant and antitumor activity. Int. J. Clin. Exp. Med. 7:483-491.

Suleria, H.A.R., M.S. Butt, F.M. Anjum, F. Saeed and N. Khalid. 2015. Onion: nature protection against physiological threats. Crit. Rev. Food Sci. Nutr. 55:5066.

Sultan, S., F.M. Anjum, M.S. Butt, N. Huma and H.A.R Suleria. 2014. Concept of double salt fortification; a tool to curtail micronutrient deficiencies and improve human health status. J. Sci. Food Agric. 94:2830-2838.

Whelton, P.K. and J. He. 2014. Health effects of sodium and potassium in humans. Curr. Opin. Lipidol. 25:75-79. 